\title{
IMPACT OF LOW QUALITY PERFORMANCE APPRAISAL ON JOB SATISFACTION, ORGANIZATIONAL COMMITMENT, AND TURN OVER INTENTION, MODERATING ROLE OF LOCUS OF CONTROL
}

\author{
MUHAMMAD BILAL \\ Air University, Islamabad, Pakistan
}

\begin{abstract}
The purpose of this paper was to examine the effect of low quality performance appraisal on three human resource management outcomes (job satisfaction organizational commitment and turnover intention); the moderating role of locus of control was also examined. Using data from 150 private sector employees, different outcomes were identified. Regression analysis indicated that low quality performance appraisal was negatively related to job satisfaction and affective commitment, whereas positively related to turnover intention. However, low quality performance appraisal was not found to have an effect on continuous commitment and normative commitment. Locus of control was found to have moderated all the relationships between independent and dependent variables.
\end{abstract}

\section{INTRODUCTION}

Performance appraisal has gained the attention of researchers since many decades (Boachie-Mensah \& Seidu, 2012; Cawley, Keeping, \& Levy, 1998; Dulebohn \& Ferris, 1999; Ferris, Judge, Rowland, \& Fitzgibbons, 1994; Ferris, Munyon, Basik, \& Buckley, 2008; Lee, 1985; Martin \& Bartol, 2003; Wright, 2004). It is considered to be a reliable source to make managerial decisions (Brown, Hyatt, \& Benson, 2010; Cleveland, Murphy, \& Williams, 1989; Latham, Almost, Mann, \& Moore, 2005; Lee, 1985). Its importance is not simply because it leads to improvement in performance (Larson, 1989; McConkie, 1979), it also leads to motivating individuals, and direct their behavior towards achieving the objectives of the organization (Khoury \& Analoui, 2004; West et al., 2002). It can be concluded from the existing body of knowledge that increasing employee performance and productivity is mostly because of the quality that performance appraisal process preserves (Brown et al., 2010).

Performance appraisal, as a critical managerial decision tool, must provide the objective and accurate ratings of an employee's performance (Boachie-Mensah $\&$ Seidu, 2012). It is extensively deemed that performance appraisal is most likely to be unfair because of high level of inaccuracy, thus users go doubtful and are reluctant in accepting the results (Banks \& Roberson, 1985). There are evidences which show that performance appraisal is affecting many organizations such that it leads to decreasing performances instead of increasing them (Latham et al., 2005). The results of performance appraisals are not always positive (Giangreco, Carugati, Sebastiano, \& Tamimi, 2012), either because of biasness in the evaluation process (Banks \& Roberson, 1985), or due to weak evaluation content (Ilgen \& Favero, 1985), or it can be because of wrong use by managers to consolidate their grip over employees (Klaas \& DeNisi, 1989), or raters would mind to provide accurate ratings due to conflict between their best interest and the ratings that are accurate (Poon, 2004). As subjectivity factor is increasing in performance appraisal systems (Boachie-Mensah \& Seidu, 2012; Choon \& Embi, 2012; Longenecker, Sims, \& Gioia, 1987; Treadway, Ferris, Duke, Adams, \& Thatcher, 2007), it is decreasing the accuracy of performance appraisals, creating negative outcomes such as decrease in organizational efficiency because of decline in the motivation of employees to perform their work. As, in existing literature, it is indicated that performance appraisal is sometimes linked to increase in job dissatisfaction and intention to quit (Kammerlind, Dahlgaard, \& Rutberg, 2004; Poon, 2004; Silverman \& Wexley, 1984; Wright, 2004), as a result organizations suffer, making it important to understand the implications of low quality performance appraisal systems (Brown et al., 2010).

This study differs from previous works in a way that this study includes a moderating role of locus of control 
which has not been proposed previously to examine its moderating effect on, e.g. job satisfaction, organizational commitment, \& turnover intention combined.

Using psychological variable such as locus of control in a moderating role can come up with different and clearer results which would be useful to understand the said relationships (Brown et al., 2010). The variations in employee attitude (e,g job satisfaction, organizational commitment) are related with employee's locus of control (Ng, Sorensen, \& Eby, 2006).

Employees having internal locus of control believe that the events can be controlled by them, while employees with external locus of control believe that they can't control their attitudes, perceptions and behaviors that are generated by an external environment (Chiu, Chien, Lin, \& Hsiao, 2005). When a person believes that some happening or event has happened because of luck, fate, or out of self-control, that person is said to have external locus of control, whereas if some event is perceived to have occurred because of self-characteristics, he/she is said to have internal locus of control (Rotter, 1966). Some past researches indicate that employees with internal locus of control are more satisfied with their jobs as compared to employees with external locus of control (Mitchell, Smyser, \& Weed, 1975).

The aim of this study is to examine the impact of low quality performance appraisal on three factors of organizational efficiency: job satisfaction, organizational commitment and turnover intention. Past researches have typically focused on single outcome of performance appraisal such as job satisfaction (Cawley et al., 1998; Jawahar, 2006b), other studies have focused on two outcomes e.g. job satisfaction and turnover intention (Poon, 2004), .little research has been done in the past to evaluate the effect on all the three factors combined (Brown et al., 2010; Jawahar, 2006a). In addition, this study is focused on analyzing the moderating effects of locus of control on the relationship between performance appraisal and its outcomes. It is expected that different results will be established. On the basis of the results, some ways may be identified to bring improvement in the current traditional way of the evaluation process.

\section{REVIEW OF LITERATURE}

\section{Assessing the quality of performance appraisal}

Performance appraisal can be described as a process of evaluation of employee performance often examined by the supervisor or a peer (DeNisi, Cafferty, \& Meglino, 1984). Performance appraisal is used for a range of purposes such as administrative and developmental uses, and is linked with organizational productivity (Behn, 2003; Cawley et al., 1998; Cleveland et al., 1989; De
Andres, García-Lapresta, \& González-Pachón, 2010; Larson, 1989; McConkie, 1979; Mount, 1984). There are evidences that employee acceptance and satisfaction with the performance appraisal process is necessary to get maximum benefits out of it (Cawley et al., 1998; Latham et al., 2005; Mount, 1984). The main focus should be to motivate employees to improve their performance, and to make it certain that appraisal ratings are unbiased, fair and are based on actual performance (Inderrieden, Keaveny, \& Allen, 1988). There are evidences that subjectivity and politics are dominant elements in performance appraisal process, which generates negative outcomes such as decrease in performance (Longenecker et al., 1987). Evaluation process mostly depicts the biasness of the appraiser, rather than the actual performance of the employee (Latham et al., 2005). From the above discussion it can be concluded that performance appraisal is a key practice that either makes the organization have enthusiastic and productive workforce, or low and demotivated employees. When positive results, such as improved performance, are not produced, then it is often attributed to the low quality of performance appraisal process (Choon \& Embi, 2012; Johnson, Batey, \& Holdsworth, 2009).

From the above discussion it can be concluded that low quality performance appraisal refers to the condition when appraiser fails to elicit in his/her ratings the actual performance of the employee, which may be due to unintentional biasness, or due to politics as a deliberate attempt to manipulate the appraisal ratings.

In sum, quality of the performance appraisal can be determined by its overall impact on HRM outcomes. Currently three HRM outcomes are included in the study, which are job satisfaction, organizational commitment and turnover intention.

\section{Low quality performance appraisal and job satisfaction}

Job satisfaction is the employee attitude or orientation which indicates the degree to which he or she likes the job (Agho, Price, \& Mueller, 1992; Beer, 1964; Brooke, Russell, \& Price, 1988; Currivan, 2000), and has been a measuring source of employee wellbeing (Green, 2004). Performance appraisal relationship with job satisfaction has been extensively studied (e.g., Blaue, 1999; Cropanzano, Howes, Grandey, \& Toth, 1997; Jawahar, 2006a, 2006b; Levy \& Williams, 1998; Poon, 2004; Vigoda, 2000). Feelings of self-worth, achievement, positive attitude towards the job, and feelings of a positive standing in the organization are the outcomes of a high quality performance appraisal (Lind \& Tyler, 1988). Past studies suggest that high quality performance appraisals are likely to generate higher 
levels of job satisfaction (Byrne \& Zinta, 2005; Fried \& Ferris, 1987; Masterson, Lewis, Goldman, \& Taylor, 2000). Feedback accuracy about performance has been observed as a key factor to an employee's ability to perform more effectively in the organization (Nathan, Mohrman, \& Milliman, 1991). There is evidence that employee satisfaction with performance appraisal is positively related with overall job satisfaction (Jawahar, 2006a), whereas on the other hand, Blaue (1999) found that dissatisfaction with performance appraisal leads to job dissatisfaction. Literature indicates that biasness in appraisal is considered to be unjust and unfair, hence it leads to lower job satisfaction (Baird, 1977; Poon, 2004; Taylor, Tracy, Renard, Harrison, \& Carroll, 1995; Vigoda, 2000). If an employee, who gives value to the organization, receives negative ratings, this would result in conflicts and lower job satisfaction. Therefore, it can be hypothesized that:

\section{Hypothesis 1.Lowqualityperformanceappraisal is negatively related to job satisfaction.}

\section{Lowqualityperformanceappraisalandorganizational commitment}

Organizational commitment refers to the extent to which an employee feels loyal, attached and involved in the particular organization (Allen \& Meyer, 1990; Mueller, Wallace, \& Price, 1992). The main purpose of performance appraisal is to elevate organizational commitment which may ultimately lead to increase in organizational productivity (Fletcher \& Williams, 1996). Employees who are contented with performance appraisal feedback tend to have higher levels of commitment (Jawahar, 2006a). Past studies suggest that two dimensions of organizational commitment are definite such as continuance and affective commitment (Allen \& Meyer, 1990). The continuance commitment entails that an employee seeks to remain with a particular organization either due to fear of losing his/ her investment in that organization, time and the effort exerted for better outcomes, or because of lack of any other job possibility(Mayer \& Schoorman, 1992). Quality performance appraisal gives an employee recognition for his/her contributions to the organization. As a result, continuance commitment may be expected to strengthen due to increase in satisfaction with performance appraisal process. The affective commitment refers to employee's strong emotional attachment and involvement with the organization for its welfare (Allen \& Meyer, 1990). Satisfaction with performance appraisal gives an employee feelings of equity and gratitude which may lead to developing emotional attachment with the organization (Lind \& Tyler, 1988). The third form of commitment, the normative commitment refers to employee's feelings of obligation to be persistent in the organization, and avoid leaving the organization despite the availability of alternatives (Allen \& Meyer, 1990). Previous studies suggest that when an employee experience high quality performance appraisals, a feeling of obligation towards the employer and the organization gets generated, which ultimately leads to the positive attitude and behavioral change (Hetidrix, Robbins, Miller, \& Summers, 1999). Employee's organizational commitment is very much dependent on its trust on appraisal system (Robinson, Kraatz, \& Rousseau, 1994). A high quality performance appraisal should make the employee feel valued and gratified to the organization (Brown et al., 2010). There is evidence which suggests that employees who believe that their contribution are appreciated and acknowledged are more committed to the organization (Masterson et al., 2000; Pearce \& Porter, 1986). Outcome of low quality appraisal mostly increases job dissatisfaction which ultimately leads to lower organizational commitment (Atwater, Waldman, Atwater, \& Cartier, 2000; Kuvaas, 2006). In an earlier study, it was found that negative appraisal ratings significantly resulted in decreased organizational commitment, whereas positive ratings did not affect organizational commitment of those employees (Pearce \& Porter, 1986). From the above discussion it can be anticipated that if there is low quality performance appraisal in the organization, then employers may experience lower organizational commitment on the part of its employees. Therefore, on the basis of the arguments given above, the following hypethesis:

\section{Hypothesis 2a. Low quality performance appraisal is negatively related to the affective commitment. \\ Hypothesis 2b. Low quality performance appraisal is negatively related to the continuance commitment. \\ Hypothesis 2c. Low quality performance appraisal is negatively related to the normative commitment.}

\section{Low quality performance appraisal and turnover intention}

Turnover intention can be defined as the behavioral intention to leave or quit the organization(Kuvaas, 2006). Past researches suggest that fairness and justice in organization are linked positively to job satisfaction and negatively to turnover intention (Chen, Ployhart, Thomas, Anderson, \& Bliese, 2011; Konovsky \& Cropanzano, 1991; Poon, 2004; Taylor et al., 1995). Satisfaction with the performance appraisal indicates 
that employees perceives that their contributions had been accurately weighed and acknowledged (Jawahar, 2006a). This may be negatively associated to turnover intention. There are empirical findings that fairness in organizations reduce the negative effects of perceived politics and biasness on turnover intention (Byrne \& Zinta, 2005; Masterson et al., 2000). Past studies suggest that low quality performance appraisal leads to lower organizational commitment (Kuvaas, 2006), and low organizational commitment is signified as the strongest predictor of turnover intention (Angle \& Perry, 1981; Geurts, Schaufeli, \& Rutte, 1999). Furthermore, it was reported that low quality appraisal was causing employees to have increased intention to leave the organization due to reduction in job satisfaction (Poon, 2004). Dominance of politics and biasness in the appraisal system may generate intentions among employees to leave the organization to avoid from being affected by biasness and political on-goings (Geurts et al., 1999; Poon, 2004; Vigoda, 2000). This low quality performance appraisal may lead to increased turnover intention (Brown et al., 2010). From the above discussion, it can be expected that low quality performance appraisal will results in lessening the willingness of the employee to remain connected to the organization, hence:

Hypothesis 3. Lowqualityperformanceappraisal is positively related to turnover intention.

\section{Locus of control as moderator}

Locus of control indicates the distinctions in the tendency towards the belief that environmental events are within one's control, as contrasted with being incapable of having such control (Krenl, 1992; Rotter, 1966). It can be categorized as Internals and Externals. Internals are those who believes that they have some control over outward happenings, and that such events are because of their own attitude and behavior, while externals are quite passive as they tends to believe that whatever happens around them happens by fate, chance or controlled by other people (Chiu et al., 2005). The internals tend to go for greater attempts to have a stronger control over their environment than externals (Blau, 1987), hence, internals are more likely to take a vigorous stance with their environment, while externals on other hand, may remain uninvolved in such activities (Krenl, 1992).

Research studies cued that psychological variables can show different results which can lead to better understanding of phenomena under study (Larwood, Wright, Desrochers, \& Dahir, 1998).

The employees having internal locus of control are more committed to their organization than employees having external locus of control (Coleman, Irving, \& Cooper, 1999; Perrewé, 1986; Spector, 1982). Further research studies indicate that internals are more likely to have intentions to quit, while externals are less likely to have such intentions to quit (Krenl, 1992; Mitchell et al., 1975). Furthermore, Blau (1987) revealed that there exists negative relationships of internals with satisfaction and turnover, as opposed to externals (Blau, 1987). A study by Keller (1984) expressed that internals are more likely to have strong intentions to leave the unfavorable job, as opposed to externals.

From the arguments above, it can be anticipated that locus of control will moderate the relationship between low quality performance appraisal and behavioral variable ssuch as job satisfaction, organizational commitment and turnover intention. Hence,

Hypothesis 4. Locus of control moderates the relationship between the low quality performance appraisal and job satisfaction.

Hypothesis 5a. Locus of control moderates the relationship between the low qualityperformance appraisal and affective commitment.

Hypothesis 5b. Locus of control moderates the relationship between the low quality performance appraisal and continuance commitment.

FIGURE 1 Theoretical Model

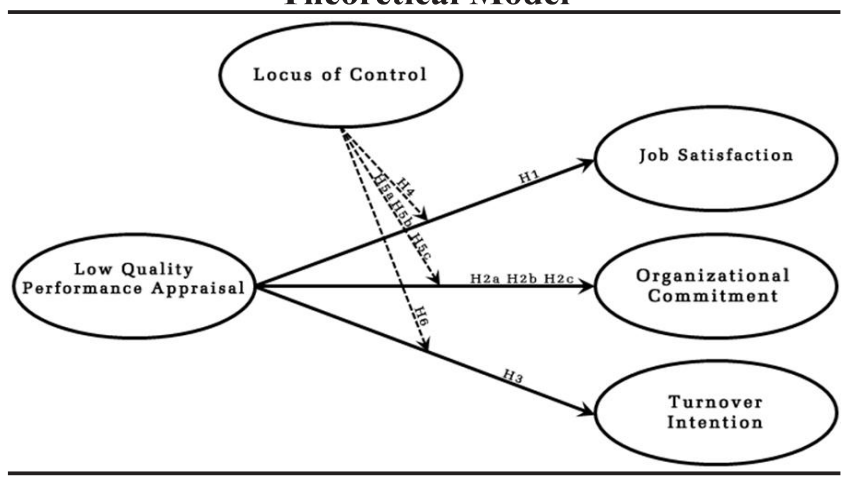

Hypothesis 5c. Locus of control moderates the relationship between the low qualityperformance appraisal and normative commitment. Hypothesis 6. Locus of control moderates the relationship between the low quality performance appraisal and turnover intention.

\section{METHODOLOGY}

\section{Sample and procedure}

The research sample included employees from 
private sector banks, telecommunication companies, and pharmaceutical firms in Pakistan. The data was collected using convenience sampling method. A cover letter clarifying the purpose and scope of the study also assured respondents of strict privacy, and that the participation was voluntary. Out of the 270 questionnaires, 125 were sent to banks (response rate: $58.4 \%$ ), 70 to telecommunication companies (response rate: $47.14 \%$ ), 75 to pharmaceuticals firms (response rate: 58.66). Overall, from the 270 questionnaires distributed, 150 responses received were usable. This represented a response rate of $55.55 \%$.

\section{Demographics}

From 150 respondents, 64\% were males and 36\% were females. Age was segmented in 5 parts where $20.7 \%$ respondents lied between age range from 18 to $24,73.3 \%$ respondents lied between age range from 26 to $34,3.3 \%$ respondents lied between age range from $36-45$, and there was no one with age limit above 55 . Regarding marital status, $54 \%$ were single and $46 \%$ were married. Similarly, $8 \%$ respondents had an experience of 6 months or less in the same organization, $14 \%$ were 6 months to 1 year experienced, $48 \%$ were 1 to 3 years experienced, $15.3 \%$ were 4 to 6 years experienced, and $14.7 \%$ reported that they had spent 7 or more years in the same organization. $30 \%$ respondents were taking salary between PKRs. 20000 and 30000, 25.3\% were taking between PKRs. 31000 and 40000, 26\% were taking between PKRs. 41000 and 50000, 7.3\% were taking between PKRs. 51000 and 59000, and 11.3\% reported that their salary ranged from PKRs. 60000 or more. Similarly, when inquired about their last education degree, $26 \%$ were bachelors, $69.3 \%$ were masters, and $4.7 \%$ were post graduates.

\section{Instrumentation}

Quality of Performance appraisal: The fairness of the performance appraisal process was measured by nineteen items scale by Tang and Sarsfield-Baldwin (1996). A sample item included "My last performance appraisal was fair". A sample item to measure the extent of communication between the employee and the supervisor included "How much opportunity are you given to express your feelings when your performance is evaluated?" A sample item to measure the level of trust in the supervisor included "How much do you trust your supervisor to accurately report your performance to his/ her supervisor?" A sample item to measure the clarity about the performance appraisal process included "When you took up your current position how clear was it that your performance would be periodically evaluated". The scale had a reliability at .93 .

\section{Job satisfaction}

Job satisfaction was measured by 9 items scale by Smith, Kendall, and Hulin (1969). A seven-point likert scale (1="Strongly Disagree" and $7=$ "Strongly Agree") was used. "I am enthusiastic about my work" is a sample item. Alpha reliability was .72 .

\section{Organizational commitment}

Organizational commitment was operationalized using Meyer and Allen's (1997) organizational commitment scale (OCS). The scale measures three distinct dimensions of commitment such as affective commitment, continuance commitment, and normative commitment. A seven-point Likert type scale (1="Strongly Disagree" and $7=$ "Strongly Agree") was used. There were reverse scored items in the OCS such as "I do not have a strong sense of belonging to my organization". These items were reversely coded when entering into the software for analysis. Affective Commitment was measured by 6 items. A representative item in this scale included "I would be very happy to spend the rest of my career in this organization." Alpha reliability was .70 . Continuance commitment was measured by 6 items. A sample item included "Right now, staying with my organization is a matter of necessity as much as desire". The reliability of the continuance commitment measure was .76. Normative commitment was assessed by 6 items. A representative item in this scale included "This organization deserves my loyalty." It has demonstrated an internal consistency reliability of .78.

\section{Turnover intention}

A three-items scale developed by Donnelly and Ivancevich (1975) was used to assess employee turnover intention. A sample item included "I often think about quitting". The reliability of the turnover intention measure was .90 .

\section{Locus of control}

Locus of control was assessed with Spector's (1988) 16-items scale. An example item reflecting external locus of control included "It takes a lot of luck to be an outstanding employee on most jobs." Conversely, "On most jobs, people can pretty much accomplish whatever they set out to accomplish" is an example of an internally worded item. Work locus of control measure demonstrated an internal consistency reliability of .76 . 
TABLE 1

Means, Standard Deviations, Correlations and Reliabilities

\begin{tabular}{|c|c|c|c|c|c|c|c|c|c|c|c|c|c|c|c|}
\hline Variable & Mean & S.D. & 1 & 2 & 3 & 4 & 5 & 6 & 7 & 8 & 9 & 10 & 11 & 12 & 13 \\
\hline 1. Age & 1.88 & 0.57 & & & & & & & & & & & & & \\
\hline 2. Gender & 1.36 & 0.48 & .10 & & & & & & & & & & & & \\
\hline 3. Marital Status & 1.46 & 0.50 & $.44 * *$ & $.47 * *$ & & & & & & & & & & & \\
\hline 4. Tenure & 3.14 & 1.08 & $.52 * *$ & $.30 * *$ & $.47 * *$ & & & & & & & & & & \\
\hline 5. Monthly Salary & 2.44 & 1.29 & $.57 * *-($ & $-0.22 * *$ & $.32 * *$ & $.52 * *$ & & & & & & & & & \\
\hline 6. Education & 1.78 & 0.51 & .02 & -.14 & .01 & .08 & .00 & & & & & & & & \\
\hline 7. Performance Appraisal & 3.15 & 0.82 & -.08 & $.42 * *$ & $.42 * *$ & $.35^{* *}$ & $-.17 *$ & -.00 & $(.93)$ & & & & & & \\
\hline 8. Job Satisfaction & 4.17 & 0.91 & .05 & .03 & $-.21 * *$ & $-.34 * *$ & -.13 & -.14 & $-.42 * *$ & $(.72)$ & & & & & \\
\hline 9. Affective Commitment & 4.26 & 1.31 & -.01 & -.12 & $-.26 * *$ & -.15 & -.04 & $.24 * *$ & $-.53 * *$ & -.12 & $(.70)$ & & & & \\
\hline 10. Continuance Commitment & 4.17 & 1.03 & -.06 & .01 & .03 & .15 & $.19^{*}$ & $-.28 * *$ & $.20 *$ & $.37 * *$ & $-.51 * *$ & $(.76)$ & & & \\
\hline 11. Normative Commitment & 3.62 & 1.24 & $-.17^{*}$ & $.16^{*}$ & .00 & $-.27 * *$ & $-.18 *$ & $-.44 * *$ & .07 & $.50 * *$ & $-.46^{* *}$ & $44 * *$ & $(.78)$ & & \\
\hline 12. Turnover Intention & 3.34 & 1.65 & .00 & $.25^{* *}$ & $.43 * *$ & $.41 * *$ & $.22 * *$ & -.02 & $.61 * *$ & $-.74 * *$ & -.09 & $-.05-$ & $-.25 * *$ & $(.90)$ & \\
\hline 13. Locus of Control & 4.15 & 0.55 & -.09 & $.52 * *$ & $.37 * *$ & $.30 * *$ & .02 & -.20 & $.56^{* *}$ & $-.25 * *$ & $-.26^{* *}$ & $.22 * *$ & -.04 & $.42 * *$ & $(.76)$ \\
\hline
\end{tabular}

\section{RESULTS}

TABLE 2

Results of Regression Analyses for Outcomes

\begin{tabular}{|c|c|c|c|c|c|c|c|c|c|c|c|c|c|c|c|}
\hline \multirow[b]{2}{*}{ Predictors } & \multicolumn{3}{|c|}{ Job Satisfaction } & \multicolumn{3}{|c|}{$\begin{array}{c}\text { Affective } \\
\text { Commitment }\end{array}$} & \multicolumn{3}{|c|}{$\begin{array}{l}\text { Continuance } \\
\text { Commitment }\end{array}$} & \multicolumn{3}{|c|}{$\begin{array}{c}\text { Normative } \\
\text { Commitment }\end{array}$} & \multicolumn{3}{|c|}{ Turnover Intention } \\
\hline & $\beta$ & $\mathbf{R}^{2}$ & $\Delta \mathbf{R}^{2}$ & $\boldsymbol{\beta}$ & $\mathbf{R}^{2}$ & $\Delta \mathbf{R}^{2}$ & $\boldsymbol{\beta}$ & $\mathbf{R}^{2}$ & $\Delta \mathbf{R}^{2}$ & $\boldsymbol{\beta}$ & $\mathbf{R}^{2}$ & $\Delta \mathbf{R}^{2}$ & $\boldsymbol{\beta}$ & $\mathbf{R}^{2}$ & $\Delta \mathbf{R}^{2}$ \\
\hline \multicolumn{16}{|l|}{ Step 1} \\
\hline Control Variable & & .28 & & & .17 & & & .19 & & & .30 & & & .37 & \\
\hline \multicolumn{16}{|l|}{ Step 2} \\
\hline $\begin{array}{l}\text { Low Quality } \\
\text { Performance } \\
\text { Appraisal }\end{array}$ & $-.34 * * *$ & .35 & $.06 * * *$ & $-.64 * * *$ & .39 & $.21 * * *$ & $.30 * *$ & .24 & $.04 * *$ & -.12 & .31 & .00 & $.56^{* * *}$ & .53 & $.16^{* * *}$ \\
\hline
\end{tabular}

$n=150$ control variables were age, gender, marital status, tenure, salary and education.

$* p<.05, * * p<.01, * * * p<.001$

\section{Control variables}

Six demographic variables were dealt as controlled variables such as Age, gender, marital status, tenure, monthly salary and education in regression analysis.

Table 1 presents the means, standard deviations, correlations, and reliability coefficients of the study variables. Respondents reported a mean level of job satisfaction at 4.17 , (s.d. 0.91), mean of affective commitment scores at 4.26 (s.d. 1.31), mean of continuance commitment at 4.17 (s.d. 1.03), furthermore, mean of normative commitment at 3.62 (s.d. 1.24), and mean score of turnover intention at 3.34 (s.d. 1.65). Performance appraisal quality assessment's mean was reported at 3.15 (s.d. 0.82). Low quality performance appraisal was found to be significantly related to job satisfaction ( $\mathrm{r}=\square .42$, $\mathrm{p}<.01)$, affective commitment $(\mathrm{r}=\square .53, \mathrm{p}<.01)$, continuance commitment $(\mathrm{r}=.20, \mathrm{p}<.05)$ and turnover intention $(\mathrm{r}=.61, \mathrm{p}<.01)$.

The bivariate associations shown in the correlation matrix indicates support for hypotheses dealing with job satisfaction, turnover intention, and partial support for organizational commitment dimensions as affective commitment was supported, whereas continuance commitment and normative commitment hypothesis were not supported.

\section{Regression Analyses}

In regression analyses several hierarchical regression analyses were performed to test the hypotheses. In all the regressions, age, gender, marital status, tenure, salary and education were dealt as control variables in the first step.

\section{Job satisfaction}

The hypothesis that proposed that low quality 
performance appraisal was negatively related to job satisfaction; to test this hypothesis, low quality performance appraisal was regressed on job satisfaction (see table 2). A negative relationship was found for job satisfaction $(\beta=\square .34, p<.001)$, this finding support the hypothesis 1 .

\section{Organizational commitment}

The hypothesis which proposed that low quality performance appraisal was negatively related to the affective commitment, continuance commitment, and normative commitment; as shown in Table 2, low quality performance appraisal $(\beta=\square .64, \mathrm{p}<.001)$ was negatively related to affective commitment, supporting Hypothesis 2a. Low quality performance $(\beta=.30, \mathrm{p}<$ $.01)$ showed positive relationship with Continuance commitment which didn't support the hypothesis $2 \mathrm{~b}$. In hypothesis $3 \mathrm{a}$, low quality performance appraisal $(\beta=$ $\square .12, \mathrm{p}<.20$ ) relationship was examined with normative commitment but the result showed that there was no significant relationship between low quality performance appraisal and normative commitment, hence hypothesis $2 \mathrm{c}$ was not supported.

\section{Turnover intention}

The hypothesis that proposed that low quality performance appraisal was positively related to turnover intention; results presented in table 2 (low quality performance appraisal $\beta=.56, \mathrm{p}<.001)$, supports hypothesis 3 .

\section{Moderator analyses}

Moderated regression analysis was used to examine the effects of locus of control. First, control variables were entered into the model. In the second step, low quality performance appraisal and locus of control were entered and controlled. Then in the last step, the interaction term was entered. As shown in Table 3, interaction term explains $50 \%$ variance $(\mathrm{R}$ square $=0.50$ ), a noticeable additional explanation of this variance was added into the equation, as demonstrated by a significant $\mathrm{R}$ square change ( $\mathrm{R}$ square change $=.15$ ). Thus, hypothesis 4 was accepted showing that locus of control moderates the relationship between low quality performance appraisal and job satisfaction. Hypothesis $5 \mathrm{a}, 5 \mathrm{~b}$ and $5 \mathrm{c}$ which hypothesized that locus of control moderates the relationship between low quality performance appraisal and affective commitment, continuance commitment and normative commitment respectively, as shown in Table 3, interaction term explained $63 \%$ variance in affective commitment $(\mathrm{R}$ square $=0.63)$, $34 \%$ in continuance commitment $(\mathrm{R}$ square $=0.34)$ and $46 \%$ variance in normative commitment $(\mathrm{R}$ square $=0.46$ ). Additional justification of this variance was established by a significant $\mathrm{R}$ square change value of ( $\mathrm{R}$ square change $=.23$ ) for affective commitment, $(\mathrm{R}$ square change $=.10)$ for continuance commitment, and for normative ( $\mathrm{R}$ square change $=.07$ ) was examined. Thus Hypothesis $5 \mathrm{a}, 5 \mathrm{~b}$ and $5 \mathrm{c}$ were accepted. Hypothesis 6 , as it was assumed that locus of control moderates the relationship between low quality performance appraisal and turnover intention, was accepted by $65 \%$ variance $(\mathrm{R}$ square $=.65)$ and $(\mathrm{R}$ square change $=.12$ ).

TABLE 3

Results of Moderator Regression Analysis

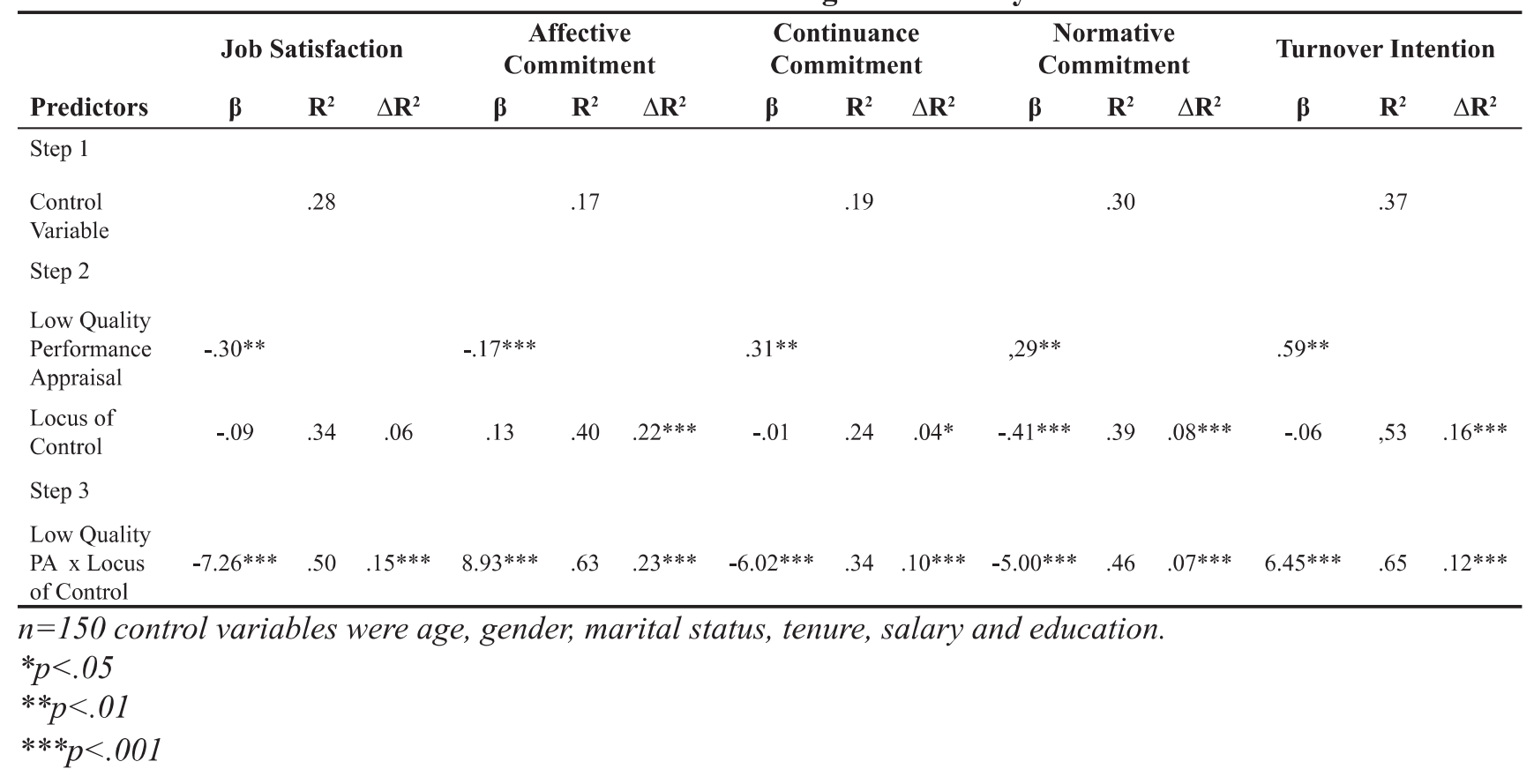




\section{Summary of Results}

To summarize the results, Hypotheses 1, 2a, 2b and $2 \mathrm{c}$ predicted a negative relationship between low quality performance appraisal and job satisfaction, affective commitment, continuance commitment and normative commitment respectively. Hypotheses 1 and $2 \mathrm{a}$ were confirmed while for $2 \mathrm{~b}$ and $2 \mathrm{c}$ were not supported. Moreover, hypothesis 3 that predicted positive relationship between low quality performance appraisal and turnover intention was well supported and confirmed.

Hypotheses 4, 5a, 5b, 5c and 6 stated that locus of control moderates the relationship between low quality performance appraisal and job satisfaction, affective commitment, continuance commitment, normative commitment and turnover intention respectively. All hypotheses were supported.

\section{DISCUSSION}

Performance appraisal quality was the basic variable in this research study. When the performance appraisal is manipulated, owing to supervisor's self-interest or for other political reasons, such manipulations make the performance appraisal lose their main aim which is to evaluate the actual performance of employees so that it can be used for several outcomes, most importantly, for decision making. When employees perceive the evaluation results to be unrealistic, they experience reduced job satisfaction. Results of this research is parallel with Brown et al. ( 2010) and Poon's (2004) empirical studies. This study attempted to examine the effects of low quality performance appraisal on organizational commitment's three dimensions. It was assumed that a negative relationship exists between low quality performance appraisal and affective commitment; a study by Shore and Wayne (1993) explained that if job satisfaction is reduced, then affective commitment is the strongest component of organizational commitment that gets affected as well. As affective commitment is based on emotional attachment with the organization, so it can be speculated that they are more sensitive and vulnerable to react to the undesirable results. In this study we found that low quality performance appraisal was positively related to turnover intention. This result is parallel with other studies (e.g., Brown et al., 2010; Poon, 2004). When performance ratings are manipulated, then overall effect is negative, which was expected. As a result, reduction in job satisfaction and affective commitment leads to turnover intention.

This study joins the growing body of research in both HRM and organizational justice domain. Attempt was to develop an understanding of how injustice effects the attitude related to HR practices in the organization.

\section{Limitations}

Like in all research studies, the present study also has some limitations. This study involved only private sector companies. Also, the sample size was small, hence, it is recommended to involve public sector companies and include large sample size for similar research studies in future. Furthermore, a longitudinal study can contribute more towards understanding the same phenomena.

For this study, three variables were examined as outcomes of low quality performance appraisal. For future studies, different outcomes such as organization cynicism and deviant workplace behavior can also be taken. For moderation, variables like trust, and fairness perceptions can be considered as well.

This study determines the importance of performance appraisal in organizations related to employees' behavior which can have negative impact on the productivity of the organization. Decision making should be made on high quality performance appraisal rather than low quality performance appraisal. It is empirically proven that performance appraisal should be carried out with care to maximize its positive impact. If not, then it can have devastating and demoralizing effects on the employees, affecting the organization as a whole.

\section{REFERENCES}

Agho, A. O., Price, J. L., \& Mueller, C. W. (1992). Discriminant validity of measures of job satisfaction, positive affectivity and negative affectivity. Journal of Occupational and Organizational Psychology, 65(3), 185-195.

Allen, N. J., \& Meyer, J. P. (1990). The measurement and antecedents of affective, continuance and normative commitment to the organization. Journal of Occupational Psychology, 63(1), 1-18.

Angle, H. L., \& Perry, J. L. (1981). An empirical assessment of organizational commitment and organizational effectiveness. Administrative Science Quarterly, 1-14.

Atwater, L. E., Waldman, D. A., Atwater, D., \& Cartier, P. (2000). An upward feedback field experiment: supervisors' cynicism, reactions, and commitment to subordinates. Personnel Psychology, 53(2), 275-297.

Baird, L. S. (1977). Self and superior ratings of performance: As related to self-esteem and satisfaction with supervision. Academy of Management Journal, 20(2), 291-300.

Banks, C. G., \& Roberson, L. (1985). Performance 
appraisers as test developers. Academy of Management Review, 10(1), 128-142.

Beer, M. (1964). Organizational size and job satisfaction. Academy of Management Journal, 7(1), 34-44.

Blaue, G. (1999). Testing the longitudinal impact of work variables and performance appraisal satisfaction on subsequent overall job satisfaction. Human Relations, 52(8), 1099-1113.

Boachie-Mensah, F., \& Seidu, P. A. (2012). Employees' Perception of Performance Appraisal System: A Case Study. International Journal of Business and Management, 7(2), p73.

Brooke, P. P., Russell, D. W., \& Price, J. L. (1988). Discriminant validation of measures of job satisfaction, job involvement, and organizational commitment. Journal of Applied Psychology, 73(2), 139.

Brown, M., Hyatt, D., \& Benson, J. (2010). Consequences of the performance appraisal experience. Personnel Review, 39(3), 375-396.

Byrne, \& Zinta, S. (2005). Fairness reduces the negative effects of organizational politics on turnover intentions, citizenship behavior and job performance. Journal of Business and Psychology, 20(2), 175-200.

Cawley, B. D., Keeping, L. M., \& Levy, P. E. (1998). Participation in the performance appraisal process and employee reactions: A meta-analytic review of field investigations. Journal of Applied Psychology, 83(4), 615.

Chen, G., Ployhart, R. E., Thomas, H. C., Anderson, N., \& Bliese, P. D. (2011). The power of momentum: A new model of dynamic relationships between job satisfaction change and turnover intentions. Academy of Management Journal, 54(1), 159181 .

Chiu, C. K., Chien, C. S., Lin, C. P., \& Hsiao, C. Y. (2005). Understanding hospital employee job stress and turnover intentions in a practical setting: the moderating role of locus of control. Journal of Management Development, 24(10), 837-855.

Choon, L. K., \& Embi, M. A. (2012). Subjectivity, Organizational Justice and Performance Appraisal: Understanding the Concept of Subjectivity in Leading Towards Employees' Perception of Fairness in the Performance Appraisal. Procedia - Social and Behavioral Sciences, 62(0), 189-193. doi: http://dx.doi.org/10.1016/j. sbspro.2012.09.030

Cleveland, J. N., Murphy, K. R., \& Williams, R. E. (1989). Multiple uses of performance appraisal: Prevalence and correlates. Journal of Applied Psychology, 74(1), 130.
Coleman, D. F., Irving, G. P., \& Cooper, C. L. (1999). Another look at the locus of control-organizational commitment relationship: it depends on the form of commitment. Journal of Organizational Behavior, 20(6), 995-1001.

Donnelly Jr, J. H., \& Ivancevich, J. M. (1975). Role clarity and the salesman. The Journal of Marketing, 71-74.

Dulebohn, J. H., \& Ferris, G. R. (1999). The role of influence tactics in perceptions of performance evaluations' fairness. Academy of Management Journal, 42(3), 288-303.

Ferris, G. R., Judge, T. A., Rowland, K. M., \& Fitzgibbons, D. E. (1994). Subordinate influence and the performance evaluation process: Test of a model. Organizational Behavior and Human Decision Processes, 58(1), 101-135.

Ferris, G. R., Munyon, T. P., Basik, K., \& Buckley, M. R. (2008). The performance evaluation context: Social, emotional, cognitive, political, and relationship components. Human Resource Management Review, 18(3), 146-163.

Fletcher, C., \& Williams, R. (1996). Performance management, job satisfaction and organizational commitment. British Journal of Management, 7 , 169.

Fried, Y., \& Ferris, G. R. (1987). The validity of the job characteristics model: A review and metaanalysis. Personnel Psychology, 40(2), 287-322.

Geurts, S. A., Schaufeli, W. B., \& Rutte, C. G. (1999). Absenteeism, turnover intention and inequity in the employment relationship. Work \& Stress, 13(3), 253-267.

Giangreco, A., Carugati, A., Sebastiano, A., \& Tamimi, H. A. (2012). War outside, ceasefire inside: An analysis of the performance appraisal system of a public hospital in a zone of conflict. Evaluation and Program Planning, 35(1), 161-170.

Green, F. (2004). Work intensification, discretion, and the decline in well-being at work. Eastern Economic Journal, 30(4), 615-625.

Hetidrix, W. H., Robbins, T., Miller, J., \& Summers, T. P. (1998). Effects of Procedural and Distributive Justice on Factors Predictive of turnover. Journal of Social Behavior and Personality, 13(4), 611632.

Ilgen, D. R., \& Favero, J. L. (1985). Limits in generalization from psychological research to performance appraisal processes. Academy of Management Review, 10(2), 311-321.

Jawahar, I. M. (2006a). Correlates of satisfaction with performance appraisal feedback. Journal of Labor Research, 27(2), 213-236. doi: 10.1007/s12122006-1004-1 
Jawahar, I. M. (2006b). An investigation of potential consequences of satisfaction with appraisal feedback. Journal of Leadership \& Organizational Studies, 13(2), 14-28.

Johnson, S. J., Batey, M., \& Holdsworth, L. (2009). Personality and health: The mediating role of trait emotional intelligence and work locus of control. Personality and Individual Differences, 47(5), 470-475.

Kammerlind, P., Dahlgaard, J. J., \& Rutberg, H. (2004). Climate for improvement and the effects on performance in Swedish healthcare-a survey in the county council of Östergötland. Total Quality Management \& Business Excellence, 15(7), 909924.

Khoury, G. C., \& Analoui, F. (2004). Innovative management model for performance appraisal: the case of the Palestinian public universities. Management Research News, 27(1/2), 56-73.

Konovsky, M. A., \& Cropanzano, R. (1991). Perceived fairness of employee drug testing as a predictor of employee attitudes and job performance. Journal of Applied Psychology, 76(5), 698.

Krenl, L. (1992). The moderating effects of locus of control on performance incentives and participation. Human Relations, 45(9), 991-1012.

Kuvaas, B. (2006). Performance appraisal satisfaction and employee outcomes: mediating and moderating roles of work motivation. The International Journal of Human Resource Management, 17(3), 504-522.

Larson, J. R. (1989). The dynamic interplay between employees' feedback-seeking strategies and supervisors' delivery of performance feedback. Academy of Management Review, 14(3), 408422.

Larwood, L., Wright, T. A., Desrochers, S., \& Dahir, V. (1998). Extending latent role and psychological contract theories to predict intent to turnover and politics in business organizations. Group \& Organization Management, 23(2), 100-123.

Latham, G. P., Almost, J., Mann, S., \& Moore, C. (2005). New Developments in Performance Management. Organizational Dynamics, 34(1), 77-87. doi: http://dx.doi.org/10.1016/j.orgdyn.2004.11.001

Lee, C. (1985). Increasing performance appraisal effectiveness: Matching task types, appraisal process, and rater training. Academy of Management Review, 10(2), 322-331.

Levy, P. E., \& Williams, J. R. (1998). The role of perceived system knowledge in predicting appraisal reactions, job satisfaction, and organizational commitment. Journal of Organizational Behavior, 19(1), 53-65.
Lind, E. A., \& Tyler, T. R. (1988). The social psychology of procedural justice: Plenum Publishing Corporation.

Longenecker, C. O., Sims, H. P., \& Gioia, D. A. (1987). Behind the mask: The politics of employee appraisal. The Academy of Management Executive, 1(3), 183-193.

Martin, D. C., \& Bartol, K. M. (2003). Factors influencing expatriate performance appraisal system success: an organizational perspective. Journal of International Management, 9(2), 115132.

Masterson, S. S., Lewis, K., Goldman, B. M., \& Taylor, M. S. (2000). Integrating justice and social exchange: The differing effects of fair procedures and treatment on work relationships. Academy of Management Journal, 43(4), 738-748.

Mayer, R. C., \& Schoorman, F. D. (1992). Predicting participation and production outcomes through a two-dimensional model of organizational commitment. Academy of Management Journal, 35(3), 671-684.

McConkie, M. L. (1979). A clarification of the goal setting and appraisal processes in MBO. Academy of Management Review, 4(1), 29-40.

Mitchell, T. R., Smyser, C. M., \& Weed, S. E. (1975). Locus of control: Supervision and work satisfaction. Academy of Management Journal, 18(3), 623-631.

Mueller, C. W., Wallace, J. E., \& Price, J. L. (1992). Employee commitment resolving some issues. Work and occupations, 19(3), 211-236.

Nathan, B. R., Mohrman, A. M., \& Milliman, J. (1991). Interpersonal relations as a context for the effects of appraisal interviews on performance and satisfaction: A longitudinal study. Academy of Management Journal, 34(2), 352-369.

Ng, T. W., Sorensen, K. L., \& Eby, L. T. (2006). Locus of control at work: a meta-analysis. Journal of Organizational Behavior, 27(8), 1057-1087.

Pearce, J. L., \& Porter, L. W. (1986). Employee responses to formal performance appraisal feedback. Journal of Applied Psychology, 71(2), 211.

Poon, J. M. L. (2004). Effects of performance appraisal politics on job satisfaction and turnover intention. Personnel Review, 33(3), 322-334.

Robinson, S. L., Kraatz, M. S., \& Rousseau, D. M. (1994). Changing obligations and the psychological contract: A longitudinal study. Academy of Management Journal, 37(1), 137152.

Rotter, J. B. (1966). Generalized expectancies for internal versus external control of reinforcement. 
Psychological monographs: General and Applied, 80(1), 1.

Shore, L. M., \& Wayne, S. J. (1993). Commitment and employee behavior: comparison of affective commitment and continuance commitment with perceived organizational support. Journal of Applied Psychology, 78(5), 774.

Silverman, S. B., \& Wexley, K. N. (1984). Reaction of employees to performance appraisal interviews as a function of their participation in rating scale development. Personnel Psychology, 37(4), 703-710.

Spector, P. E. (1988). Development of the work locus of control scale. Journal of Occupational Psychology, 61(4), 335-340.

Tang, T. L. P., \& Sarsfield-Baldwin, L. J. (1996). Distributive and Procedural Justice as Related to Satisfaction and Commitment.

Taylor, M. S., Tracy, K. B., Renard, M. K., Harrison, J. K., \& Carroll, S. J. (1995). Due process in performance appraisal: A quasi-experiment in procedural justice. Administrative Science
Quarterly, 495-523.

Treadway, D. C., Ferris, G. R., Duke, A. B., Adams, G. L., \& Thatcher, J. B. (2007). The moderating role of subordinate political skill on supervisors' impressions of subordinate ingratiation and ratings of subordinate interpersonal facilitation. Journal of Applied Psychology, 92(3), 848.

Vigoda, E. (2000). Organizational politics, job attitudes, and work outcomes: Exploration and implications for the public sector. Journal of Vocational Behavior, 57(3), 326-347.

West, M. A., Borrill, C., Dawson, J., Scully, J., Carter, M., Anelay, S., . . . Waring, J. (2002). The link between the management of employees and patient mortality in acute hospitals. International Journal of Human Resource Management, 13(8), 1299-1310.

Wright, R. P. (2004). Mapping cognitions to better understand attitudinal and behavioral responses in appraisal research. Journal of Organizational Behavior, 25(3), 339-374. 